\title{
USING INTERNET AND EDUTECH BECOME A PRIMARY NEED RATHER THAN A LUXURY - THE REALITY: A NEW SKILLED EDUCATIONAL SYSTEM - DIGITAL UNIVERSITY CAMPUS
}

\author{
Professor Dr. Narcisa Roxana Moșteanu *1凶 (iD \\ ${ }^{* 1}$ Provost, AUM, Malta, Europe
}

DOI: https://doi.org/10.29121/IJOEST.v4.i6.2020.129

Article Type: Research Article

Article Citation: Professor Dr. Narcisa Roxana Moşteanu. (2020). USING INTERNET AND EDUTECH BECOME A PRIMARY NEED

RATHER THAN A LUXURY - THE REALITY: A NEW SKILLED EDUCATIONAL SYSTEM - DIGITAL UNIVERSITY CAMPUS. International Journal of Engineering Science Technologies, 4(6), 1-9. https://doi.org/10.29121/IJOEST.v 4.i6.2020.129

Received Date: 01 November 2020

Accepted Date: 16 November 2020

Keywords:

Digital Campus

Education Organizational Structure Change

Management of Changes

\begin{abstract}
Actual movements in socio-economic life around the world impose elearning and e-presence and moving digital is more than online teaching. Present research analysis was conducted on two different types of institutions: public and private universities from Europe, with different teaching and learning system: American and European. Information was congregated through face-to-face and online interaction with representative people from universities. The present research paper aims to demonstrate how a digital campus, with all its aspects, can perform a crucial role in enriching the university campus's structure and culture to ensure the quality of teaching, research, and administrative management using actual innovative technologies. More than this the present paper underlines the society benefits from implementation and running a Digital university campus, especially in a time of socio gathering restrictions.
\end{abstract}

\section{INTRODUCTION}

Technologies appear because of the quality of the education and research process, and human intelligence completes a successful future. The latest events of 2020 have shown us the benefits of technologies created by scientists, professors, researches in the field, in the innovative approach to university education - the transition from teaching and conventional research to the digital campus, through EdTech.

The scientific part in the field of society's development has always been defined by researchers and professors. The members of the academic community have led the society up to the actual times and continue their developments for the future. Economic development is fully supported by educational institutions, where the process of learning, research and innovation can take place face to face, on university campus, using its premises' facilities, or online, using digital facilities. Digital communication facilities are developing people's professional field. Therefore, humans must be supporters of the development of future society. And, monitoring closely the implementation of the required changes [1]. Professional and intellectual capacities certainly lead to the involvement

(c) 2020 The Author(s). This is an open access article distributed under the terms of the Creative Commons Attribution License, which permits unrestricted use, distribution, and reproduction in any medium, provided the original author and source are credited. 
of the young generation for the development of society in order to create sustainable added value for a balanced and lasting economic development, in conditions of social security.

The system of transmitting ideas between people, at a scientific level, can be transposed into a professional framework, using databases, time and space, which can accurately provide the information needed to organize the personal career agenda, as well as the development path of business. As the technologies evaluate and society's needs are changed, the university organizational structure and culture must change and adapt itself. Information and digital access to databases can help define any process / project / activity, providing a clear picture of the entire cycle of activities from start to finish. At the same time, the use of digital systems, on a consistent educational basis, offers the possibility to see the field of the future society where it will be, with all the elements behind it. Education will always play an important role in any country sustainable economy and a healthy environment [2]. An educated and knowledge equipped student leads to an educated family, and an educated family means an educated society (see Figure 1). Consequently, an educated society understand the importance of investment in developing the education sector, as it can help the whole society to develop and grow in a sustainable way.

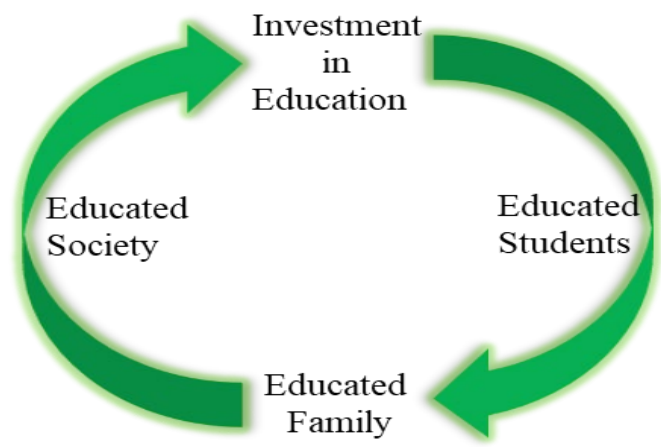

Figure 1: Return of the Investment in Education

Higher education history records more than 1600 years now. The first university was recorded in Morocco, in year 859 (it is about University of Al-Karaouine, also known as Al-Quaraouiyine University, which it was founded by Fatima al-Fihri as a community mosque with an associated school. The university still exists today). Since then and till present time, according to the Webometrics database [3], in January 2020, around the world, there are noted 24,429 universities. According with International Association of Universities [4], 30 countries record at least 100 universities (public and private) and the supremacy is held by United Stated (2116 universities), followed by Mexico, Philippines, Indonesia, Brazil and China all with more than 1000 universities (see Figure 2). Morocco was the first country in which was established the first university. Now records 157 universities, out of which 116 are private universities. The United states oldest institution is Harvard, established in 1636, 777 years later that the first in Morocco, it is one of the most worldwide recognized, and from the beginning was private, not public one. The oldest public university in the world is recorded in Italy, University of Bologna, in year 1088 (in 2020, According to International Association of Universities, Italy register 99 universities, out of which 70 are public ones).

Having in a view the current situation, Covid-19, and social distancing restrictions, majority of universities are offering face-to-face teaching and learning programs. As a general definition for a university, academicians agreed that it is an institution of higher education and research, which, based on the students' performance, it awards academic degrees/diplomas in various academic disciplines or specializations. However, the emergence of new requirements on the job market, industrial reforms and the development and implementation of new technologies have been, and still are, challenges for professors in all specializations. Teaching methods have gradually improved, to meet the needs of business's requirements, the social conditions travel restrictions, as well as the perceptions and needs of students and for those eager for professional development [5], [6], [7]. 


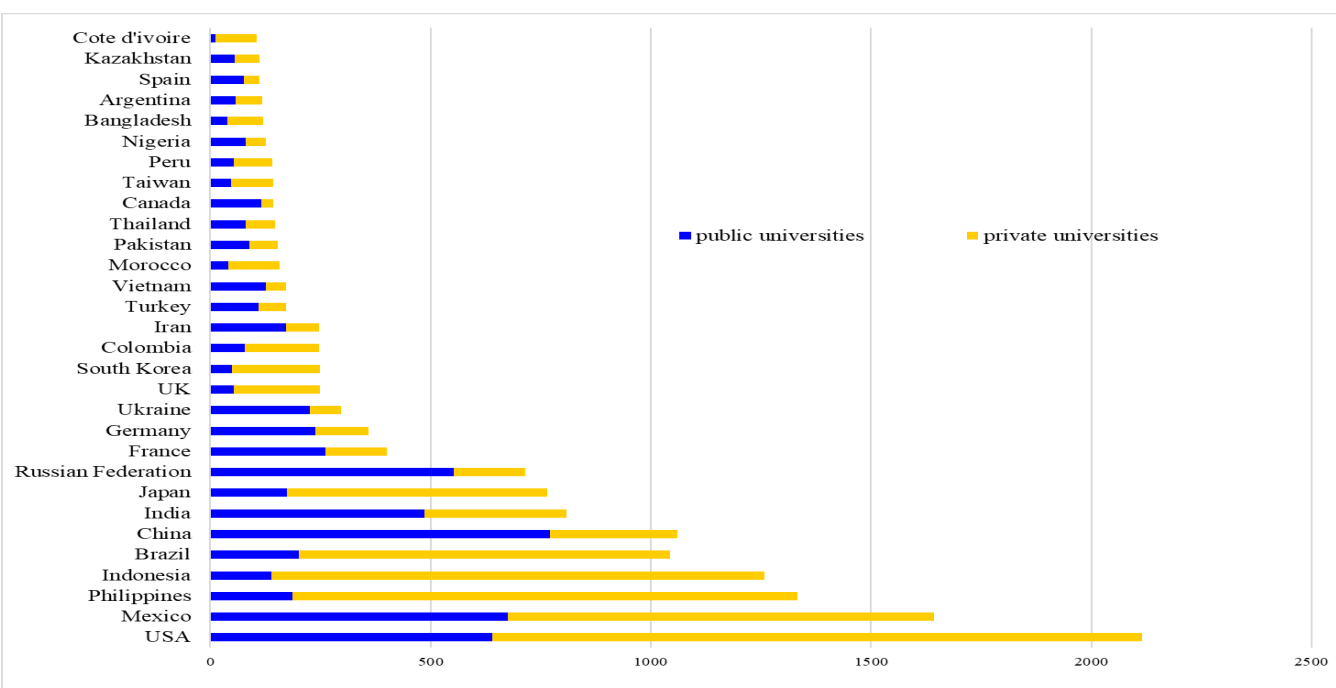

Figure 2: Countries which records more than 100 universities, in November 2020 (based on data from International Universities Association, 2020 [4])

Though, online teaching started in years 1900, at the same time with the spread of internet and the worldwide web, and now are more than 28,000 online degrees from accredited online universities and colleges [8]. Online and long-distance teaching and professional development appear to be more approachable in a social distancing restriction, for example in a pandemic crisis caused by Covind-19, in year 2020, or financial and travel difficulties [2].

Although even before 2020 pandemic crisis, there was already a trend in adoption of teaching and learning new technology, developing and offering new programs/specializations in artificial intelligence, digital systems, cybersecurity and e-marketing, after Covid-19 crisis, the global EdTech investments showed a dedicated budget allocation, which reached US $\$ 18.66$ billion in 2019 , and the overall market for online is predictable to reach US\$350 billion by 2025 . We may say that Covid-19 stimulated and urged all education institutions to make a step further and adopt digitalization and new learning and teaching platforms faster than it was previously covered in their business or strategic plan [9], [10], [11].

Nowadays, online education and digital campus is no longer a trend, it is mainstream. Therefore, changing the university organizational structure and culture and adopting the digital campus, in its whole concept, can help to have a continuity for the education process in the era of technology and socio-financial uncertainty. Since year 859 and till present investment in higher education is a continuous process which require public and private financial budget allocations. As a general understanding, investment is an activity used by the people to increase wealth, develop a business, and improve the economy. Generally, investors run the money in a way that there will be a profit [12], [13]. Investment in education is considered an advance of the gross domestic product. The product and profit of these investments are recorded / observed in the long run and consist in the high degree of professional qualification and education of the entire society [14], [15]. Universities are institutions of higher education in which human capital improvement takes place, typically through the process of teaching, learning, research and innovation. Therefore, an investment in developing the university campus based on modern technologies consequently benefits the entire economy. Moreover, the investment in a human capital development is an intelligent and sustainable instrument to be used for increasing the economic growth [16], [17], [18].

A university, and a university campus, could influence the economy through its sectoral links [16]. All economic sectors and all social categories benefit directly and/or indirectly from the expenses incurred by a university campus, whether private or public. An informed and educated society will understand better the effect of their decisions, regardless those decision is related to the private or public actions.

New technologies and digital systems have dramatically changed the organizations' structure and culture, labour market skills' requirements, and marketing environments. Whether it presents an opportunity, a test, or a need for survival, addressing this challenge depends on how organizations approach it strategically [19]. 
Digital technologies have transformed the way organizations and consumers interact and transform value [20]. For example, web 2.0 has transformed the way people access information, communicate with each other, and experience products and services [21]; 3D printing has changed the way goods are produced and consumed [22]; the Internet of Things has revolutionized the way individuals interact with physical environments; application-based mobile banking helps with digital financial transactions [23], [24]; and, universities offer training, learning and accomplishments of new skills, through digital communication [24], [25], [26], [27]. Therefore, digitalization is not a new phenomenon, and in conditions of social distancing, such as the Covid-19 pandemic of 2020, it continues to evolve and produce new effects on the organization's environment, with more emphasis on the educational system. And this because, despite disrupted routine, the whole economy needs skilled people in the years to come.

Digitalization of university campus and the need of reshaping and funding the higher education systems, it was discussed in many academic research [28], [29], with accent of the importance of the human factors: social interaction, well-designed learning experiences, participatory pedagogy, supportive teaching presence, and effective techniques for using technology to support learning [30], [31], and not only socializing.

From this point further, the present research will present the necessity and the benefits of investment in campus digitalization, both from students and universities perspective.

\section{MATERIALS AND METHODS}

The present work paper is an exploratory research, based on investigative procedures. This study was conducted on two different types of institutions: public and private universities from Europe, with different teaching and learning system: American and European. Information was assembled through face-to-face and online interviews. University representatives were asked the following questions: existence of a business continuity plan and an emergency reserve fund; the speed of adapting the university' organizational structure and culture to the changes of the environment, as well as the benefits of using the new digital technologies to ensure the business continuity. The present paper aims to identify the main changes that may occur during and after disaster, and it presents the possible ways of improving the institutional structure and culture approach in sense of university campus digitalization.

\section{RESULTS AND DISCUSSIONS}

Despite the fact that digitalization become a common word and part of our daily life, the research noticed that digital campus means more than e-learning, it includes also e-presence and e-university administration [32], and involve all academic and administrative activities conducted by the university, and is not limit to teaching, learning and research perspective [22], [33].

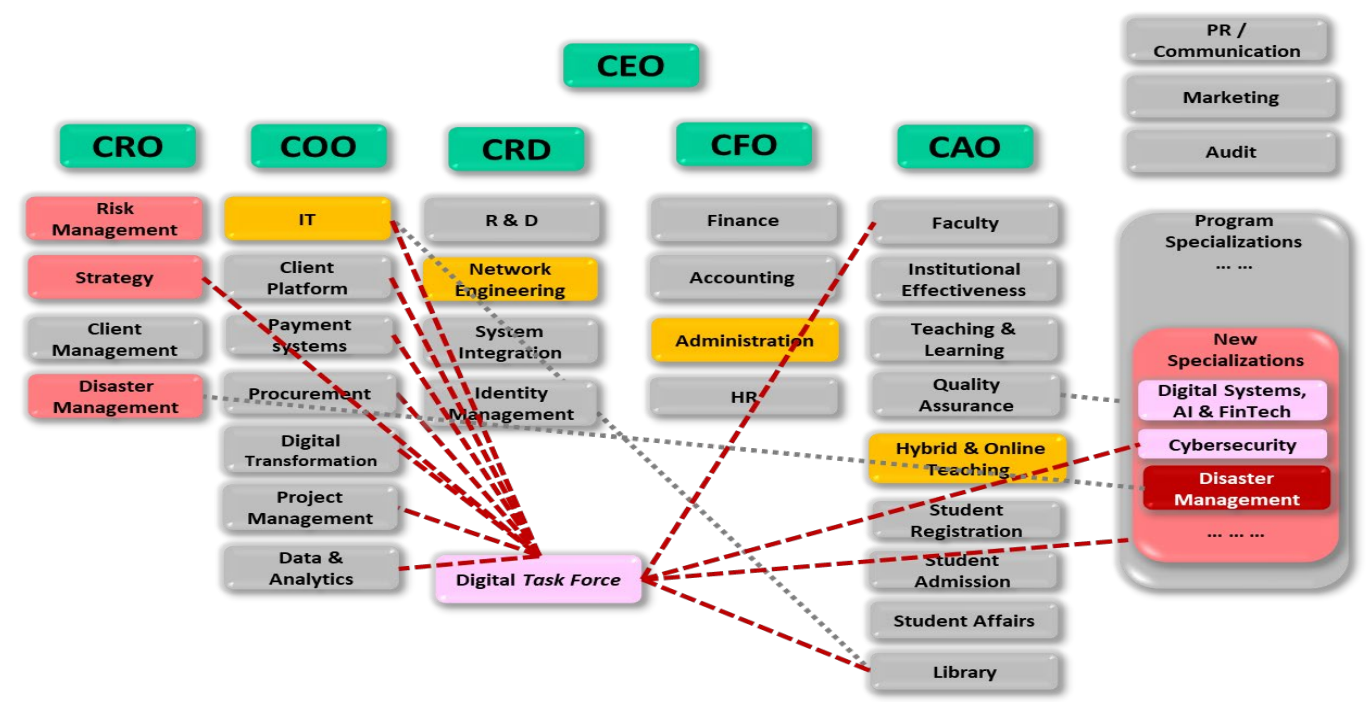

Figure 3: Organizational structure of a university [22] 
When comes about universities, regardless their teaching and learning system (American or European), the research has revealed that, in the current time, distance learning or online education is commonplace. More than that, in the event of a disaster, the transition from working/learning from face-to-face to online education can be carried out very easy and fast (as long as there is an access to internet). All we need is to have a good internet access and a good training/orientation session to learn, understand and manage to use e-communications or Learning Management System (LMS) tools (e.g. emails, MS Teams, Zoom, Skype, Canvas, Blackboard).

At the organizational level, in any university, the risk of a disaster can be taken over by the Risk Management Department or it can be create another, dedicated to management of disaster, which combines experts from IT, institutional administration, risk management, marketing, communication, digital learning (LMS) and academic administration. Digitalization helps as well. It is related to the implementation of new technologies. In case of university, digitalization requires e-Communication and ICT skills (see Figures 3 and 4). It can be very easy achieved by connecting each one of employee, faculty and student to a PC, from home. Nevertheless, it is imperative necessary to conduct workshops and orientation for LMS, involving all university community engaged in academic process (especially students and faculty members).

In an academic industry, any change in the general environment, such a disaster which comes with social and travel restrictions, is forcing the university, as an organization working with people, to adapt and/or chance its structure and culture approach and to create a new strategy to keep the process of education ongoing. However, any event should be taken as an opportunity for improvement. In this case, Covid-19 underlined the necessity to come (if the university didn't do it before) with innovative ideas for new program specializations or new courses which will able the students to have digital skills and competences.

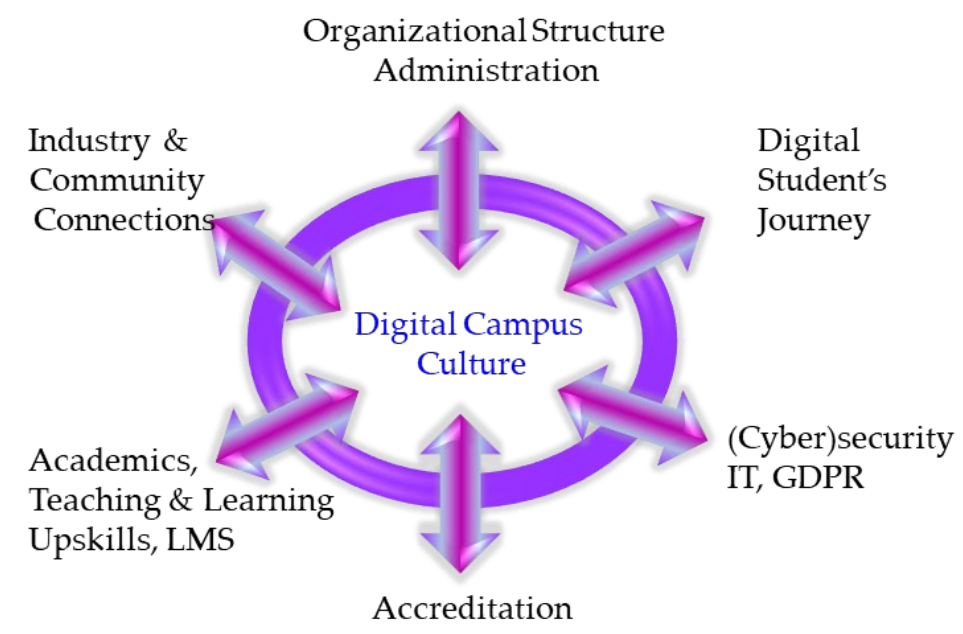

Figure 4: Digital Campus' architecture

Digital Campus development is an important part of university expansion and should meet the need of information technology development in higher education [34]. Currently, there is no standard framework for the Digital University Campus, and as technology advances, the framework will evolve organically. However, to begin the journey to provide students with an experience on the digital campus, educational institutions need to change their organizational structure and culture, and incorporate: visual experience and exposure, a high-performance IT system and the implementation of digital systems in all institutional levels (admission, registration, finance, administration, research, teaching, evaluation and many other).

The system architecture of Digital University Campus can be divided into 6 parts - Academics, Accreditation, Industry and Community Connection, Digital Student Journey, Administration, and IT, (Cyber)Security and GDPR (see Figure 4). Every part is better to be intercorrelated with each other, in an integrate information management system, to achieve the integrity and the unity of the whole university system and the effective management of their programs and other activities.

As the labor market and socio-economic needs are changing continuously, and world moves towards smart cities focusing on digital solutions for a more viable and sustainable future, higher education institutions are expected not to be left behind [35]. According with Campus Management Corporation all these 6 parts have their 
Using Internet and Edutech Become A Primary Need Rather Than A Luxury - The Reality: A New Skilled Educational System - Digital University Campus

importance and they cannot work separately [35]: Academics include learning management systems; virtual/blended and personalized learning methods; learning analytics; assessment models; 3rd party content and apps; learning aids including library and CMS. Accreditation, the recognition of quality assurance of teaching and learning is better to include academics and institutional performance (teaching and research); real time reports; infrastructure; raking; quality management systems; governance and regulation mandates; real time reports; and, compliance data. Industry and Community Connections is vital to be part of teaching and research process. They help the university to be updated to the labor market and the whole economy needs in terms of skills and knowledge, also they help the young graduated students to integrate themselves into society, through internships, workplaces and research projects developments. In this regard, the university supposed to have on its portal dedicated area to link with industry and community research projects; employment hubs; grants; and alumni. Digital student journey connects the student with all services and facilities offered by the university, provides access to identity management, ensure connection with the campus remotely. Administration and It and Security are the services management area which include human resource (both academics and administrators); finance; accounting; procurement; welfare; support functions; secure hardware; mobility/apps; 3rd party content; and secure data warehouse.

\section{CONCLUSIONS AND RECOMMENDATIONS}

Shifting from in campus teaching to online, and from Physical Campus to Digital Campus, especially during the Spring semester of academic year 2019/2020 really challenged and changed the students and the faculties perspective. Both students and faculties were exposed to online teaching and asked to use digital skills overnight. This was a real challenge, as we are talking about digital systems quite a while, changing and teaching remotely was becoming real in one night, all academic actors had to adapt sooner that they wanted or thinking to. In a couple of weeks in majority of universities around the word started orientation session for students and faculties, new communication tools started to be utilized, and many discovered that all smart devices that we are using for different apps can also be used for university facilities. More than this, administrators of the universities started to give more attention for financial resources allocated to equip students and faculties with dedicated devices able to conduct online teaching. Therefore, in the last first month of 2020, we all realize that digitalization is part of our life and, if we didn't start to use it in the past, we have to use it now.

It is true that we are living in a time of changings, economic and social behaviors are moving with the speed of thought, and every day becomes a challenge and an opportunity too, and digitalization turn into a part of everything. Today, education is called to produce skilled students able to fit the new businesses' needs. Therefore, investment in education appears more than necessary. Shifting from traditional learning to e-learning and equip the students with those qualifications and skills needed to be employable become a must not optional. In this respect, the present paper concluded that students, faculties and university's administrators have to become familiar using new learning technologies and e-communication tools. And from this perspective, Digital University Campus takes a step forward, being more than technology and going online. More than this, in a time of social and travel restrictions, through an integrated university management system, students, faculties and academic administrators can facilitate the flow of documents and approvals, without being required to step physically into the university's premises (campus).

Digital Campus is the entire academic journey and learning experience to which students are exposed. Digital Campus is more complex than online teaching, is about willingness to change safety, investments, innovation, creativity, and teamwork. The present research on the Digital Campus' services revealed that the student's journey within Digital Campus understood that the real digital campus' activities implies more aspects than what we know as e-teaching and learning or EdTech, it is imply e-presence, e-administrative services, e-finance, and others. Using e-communication tools, student' academic journey goes through many stages, which can be easily developed and conducted online.

An investment in Digital campus approach, as a technological developed perspective of higher education is more than welcome, to help the entire economy to grow in a healthy and sustainable way, by keeping the education process ongoing, regardless the socio, financial or economic restrictions.

The most beneficial approach of Digital Campus is that it is an academic education modern system which provides anytime and anywhere access to both learning, research, meeting the industry, as well as administrative content [35], [36], [37]. Access to a developed higher education system, such digital campus, it transforms the lives

International Journal of Engineering Science Technologies 
of people and society. Modern and friendly higher education system it is meant to help all people to get access to knowledge and information, despite social, travel and financial impediments or restrictions. The ability of universities to provide access to education in line with modifying behavior, changing needs and circumstances should be priorities in the actual environment, for all of us, both private or public.

The research finds out that Digital Campus is a high-tech experience, and nevertheless represents a pathway for universities to respond to 21st century society's changing needs and remain relevant, ensuring quality of teaching and learning, at the same time. Investors are always looking for their return. If the investor is the government, then the return is the increase in educational level for the whole society. From this perspective, the present research, through investigative techniques discovery out that internet access plays a crucial role. To get access to education, first we need to ensure that all communities from the entire country have access to internet, and for this public authorities are called to allocate dedicated financial resources, and to monitor the success of internet access implementation at whole country's territory, without any exception. In this way, all citizens will have access to information and professional development. If the investor is a private company, then the financial investment in education of 21st century deal with many faces: a) stimulate in house and outside digital technologies providers for educational system offered online, or face-to-face \& online blended, delivered simultaneously; encourage private industry to participate in amending teaching and learning curricula in order to equip graduate students with digital skills required for actual labor market; and, encourage the potential investor to participate in developing digital campus, as a business of the future, in education industry, as education will always be needed, regardless the economic level of the corporate or government side.

Investment in education is investment in our future safeties, and economic development is fully supported by educational institutions. Digital communication facilities are developing people's professional field. Therefore, humans must be supporters of the development of future society and start integrating digitalization in their education plans. And we have to always remember that skills and competences accumulated during all higher education programs, with an important help from e-communication and e-learning, coordinated by professional academics and managers (the core of Digital Campus) will name you an educated adult, ready to be an active actor of the community. Albert Einstein said education is what remains after one has forgotten everything, he learned in school [38] ... all skilled you accumulate within a performing university campus - which, in $21^{\text {st }}$ century, it becomes Digital.

\section{SOURCES OF FUNDING}

This research received no specific grant from any funding agency in the public, commercial, or not-for-profit sectors.

\section{CONFLICT OF INTEREST}

The author have declared that no competing interests exist.

\section{ACKNOWLEDGMENT}

None.

\section{REFERENCES}

[1] Attri, S. Perception and Importance of Mentor-Mentee Programme in Indian Institute of Technology (IIT, Jodhpur) To first year engineering student. International Journal of Engineering Science Technologies, 4(1), 2020, $19-27$.

[2] Moşteanu, N.R. Education, qualification awareness and social civism to build and sustain a healthy and developed society. Proceedings of e-EUBCE 2020, Marseille, France, 2020: 926-929.

[3] Ranking Web Universities, https://www.webometrics.info/en/node/54. Accessed 3 July 2020.

[4] International Universities Association (2020). World Higher Education Database, http://whed.net/home.php. Accessed on 5 November 2020. 
Using Internet and Edutech Become A Primary Need Rather Than A Luxury - The Reality: A New Skilled Educational System - Digital University Campus

[5] Booth, A. Learning history in university: Student views on teaching and assessment. Studies in Higher Education, 18(2), 1993, 227-235.

[6] Moşteanu N.R, Faccia A. Digital Systems and New Challenges of Financial Management - FinTech, XBRL, Blockchain and Cryptocurrencies. Quality Access to Success Journal, 21(174), 2020, 159-166.

[7] Moşteanu N.R. Artificial Intelligence and Cyber Security - A Shield against Cyberattack as a Risk Business Management Tool - Case of European Countries. Quality Access to Success Journal, 21(175), 2020, 148-156.

[8] University of People. Your Guide to the Larges Online Universities. https://www.uopeople.edu/blog/yourguide-to-the-largest-online-universities/. Accessed 3 July 2020.

[9] Li C., Lalani F. The COVID-19 pandemic has changed education forever. https://www.weforum.org/agenda/2020/04/coronavirus-education-global-covid19-online-digitallearning/. Accessed on 29 April 2020.

[10] Moşteanu N.R. Intelligent tool to prevent Economic Crisis - Fractals. A possible solution to assess the Management of Financial Risk. Quality Access to Success Journal, 20(172), 2019, 13-17.

[11] Faccia A., Moşteanu N.R., Fahed M., Capitanio F. Accounting Information Systems and ERP in the UAE. In Proceedings of 3rd International Conference on Cloud and Big Data Computing, Oxford, UK, 2019: 90-94.

[12] Moşteanu N.R. Principles of International Finance, Banking and Taxation, Publisher Universitară, Bucuresti, Romania, 2019.

[13] Moșteanu N.R, Moşteanu T., AlGhaddaf C., Butoianu M.M. Finance: Challenges of Digital Era, Publisher: Universitară, Bucuresti Romania, 2019.

[14] Moşteanu N.R. Finante Publice, 2nd ed, Publisher: Universitară, Bucuresti Romania, 2011.

[15] Moșteanu N.R. Romania' fiscal budgetary Strategy. Quality-Access to Success Journal, 12(2), 2011, 606-609.

[16] Dyason D., Kleynhans E.P. A university in a small city: Discovering which sectors benefit. Acta Commercii, 17(1), 2017, 1-13.

[17] Neeliah H., Seetanah B. Does human capital contribute to economic growth in Mauritius? European Journal of Training and Development, 40(4), 2016, 248-261.

[18] Moşteanu N.R. Efficiency of public revenues in Romania. Metalurgia International, 16(12), 2011,87-90.

[19] Quinton S., Canhoto A., Molinillo S., Pera R., Budhathoki T. Conceptualizing a digital orientation: antecedents of supporting SME performance in the digital economy. Journal of Strategic Marketing, 26(5), 2018, 427-439.

[20] Yadav M.S., Pavlou P.A. Marketing in computer-mediated environments: Research synthesis and new directions, in: Journal of Marketing, 78, 2014, 20-40.

[21] Hamill J., Tagg S., Stevenson A., Vescovi T. Editorial: Special edition-New developments in online marketing. Journal of Marketing Management, 26, 2010, 181-186.

[22] Moşteanu N.R. Management of Disaster and Business Continuity in a Digital World. International Journal of Management, 11(4), 2020, 169-177.

[23] Moșteanu N.R., Faccia A., Cavaliere L.P.L., Bhatia S. Digital technologies' implementation within financial and banking system during socio distancing restrictions - back to the future. International Journal of Advanced Research in Engineering and Technology, 11(6), 2020, 307-315.

[24] Moșteanu N.R. Finance digitalization and its impact on labour market. Technium Social Science Journal, 8, 2020, 598-605.

[25] Moșteanu N.R. Influence of financial policy about the employment in Romania. Budgetary Research Review, 3(1), 2011, 3-19.

[26] Moșteanu N.R., Faccia A., Cavaliere L.P.L. Digitalization and green economy - changes of business perspectives, in: Proceedings of 4th International Conference on Cloud and Big Data Computing (ICCBDC), 2020 August 26-28, Liverpool, UK, 2020: 108-112.

[27] Hazemi R., Hailes S., Wilbur S. The digital university: reinventing the academy. Science \& Business Media, Springer, 2012.

[28] Moşteanu N.R. Finanţarea dezvoltării regionale în România, Publisher Economica, Bucuresti, Romania, 2003.

[29] Siemens G., Gašević D., Dawson S. Preparing for the digital university: A review of the history and current state of distance, blended, and online learning. https://ictlogy.net/bibliography/reports/projects.php?idp=3138\&lang=ca, 2015. Accessed 10 July 2020.

[30] Margaryan A., Littlejohn A., Vojt G. Are digital natives a myth or reality? University students' use of digital technologies. Computers \& education, 56(2), 2011, 429-440. 
[31] Frau-Meigs D., Bossu A. Towards e-presence at distance as a way to reach and share e-quality: The case of the ECO sMOOCs". European Conference on Massive Open Online Courses, Springer, Cham, 2017: 38-47.

[32] Moşteanu N.R., Faccia A., Cavaliere L.P.L. Disaster Management - Digitalization and Financial Resources important factors to keep the organization ongoing. Proceedings of 4th International Conference on Cloud and Big Data Computing (ICCBDC), 2020 August 26-28, Liverpool, UK, 2020: 118-122.

[33] Dynasign Campus Live in Action. Digital Signage Magazine, 9(3), 2014, 16.

[34] Campus Management Corporation - Digital campus. Consumerization of technology and expectations from higher education institutions - Education 4.0 Webinar Series. Accessed on 20 May 2020.

[35] Moșteanu N.R. Challenges for Organizational Structure and design as a result of digitalization and cybersecurity, in: The Business management Review, 11(1), 2020, 278-286.

[36] Moşteanu N.R. Digital Campus - a future former investment in education for a sustainable society, in The International Conference on Innovation and Modern Applied Science in Environment Studies, Kenitra, Morocco, December, 2020. In press.

[37] Moşteanu N.R. Socio-Financial Disruption - Key tips to manage and ensure the business continuity, in: Global Journal of Social Sciences Studies, 6(2), 2020, 87-95.

[38] Einstein A., Westreich B. Education. Press of Arden Park, New York, USA: 1950. 